\title{
Association between Inflammatory Markers and Glycemic Control in Korean Diabetic Patients
}

\author{
Min Kang ${ }^{1}$, Seok-Joon Sohn ${ }^{2}$ \\ ${ }^{1}$ Graduate Student, Department of Public Health, Graduate School, Chonnam National University, Hwasun-gun; ${ }^{2}$ Professor, Department of Preventive \\ Medicine, Chonnam National University Medical School, Hwasun-gun, Korea
}

Objectives: This study evaluated the association between inflammatory markers and glycemic control in Korean patients with diabetes mellitus. Methods: Using data from the 2007-2018 Korean National Health and Nutritional Examination, 4,186 diabetic subjects aged between 19 and 80 years were included in this study. Poor glycemic control was defined as level of $\mathrm{HbA} 1 \mathrm{c}$ higher than $7 \%$. Inflammation was measured by inflammatory markers including white blood cell (WBC) count and high-sensitivity C-reactive protein (hsCRP), and those inflammatory markers were categorized into 4 groups by quartiles. A multiple logistic regression analysis was performed to evaluate the association between quartile of inflammatory markers and poor glycemic control after adjusting for demographic factors, lifestyle, and comorbidities. Results: Levels of WBC count and hsCRP were positively associated with the risk of poor glycemic control even after fully adjusting for potential confounders. For WBC count, compared with the first quartile, the second quartile was 1.50 (95\% confidence interval, Cl: 1.26-1.78), 1.71 (95\% Cl:1.43-2.05) for the third, 2.00 (95\% Cl: 1.67-2.40) for the fourth. In case of hsCRP, compared with the first quartile, the second quartile was 1.15 (95\% Cl: $0.87-1.53)$, 1.59 (95\% Cl: 1.20-2.11) for the third, and 1.59 (95\% Cl: 1.19-2.12) for the fourth. There was significant age difference in the association between hsCRP and glycemic control. The association was more evident in the younger group than in the elderly group. Conclusions: High level of WBC and hsCRP were positively associated with the risk of poor glycemic control. These results suggest that in a Korean diabetic patient, inflammation was significantly associated with poor glycemic control.

Key words: Leukocyte, C-reactive protein, Inflammation, Glycated hemoglobin, Diabetes mellitus

\section{INTRODUCTION}

The prevalence of diabetes mellitus (DM) continuously increases worldwide. The estimated prevalence of DM in Korea is approximately $11 \%$ [1], higher than prevalence of DM in Organization for Economic Cooperation and Development (OECD) average of 7\% [2]. Furthermore, the social and economic burden of DM and its complications are also rapidly increasing [3]. DM is a metabolic disorder characterized by elevated blood glucose levels, and can be subdivided into 2 types [4]. Type $1 \mathrm{DM}$ is a result of autoimmune beta-cell destruction in pancreas and pancreas fails to secrete insulin. Type $2 \mathrm{DM}$ (T2DM) occurs when insulin-resistance (IR) increases abnormally and the pancreas cannot produce sufficient

\section{Corresponding author: Seok-Joon Sohn}

264 Seoyang-ro, Hwasun-eup, Hwasun-gun 58128, Korea

Tel: +82-61-379-2621, E-mail: sohnsjx@jnu.ac.kr

Received: May 5, 2021 Revised: June 7, 2021 Accepted: June 7, 2021

*This thesis is the first author Min Kang's doctoral dissertation from Chonnam National University Graduate School of Department of Public Health.

No potential conflict of interest relevant to this article was reported. insulin to overcome that resistance $[5,6]$. DM causes variety of complications such as coronary artery disease (CAD), kidney disease, neuropathy, blindness, and risk of lower-extremity amputation [5], all complications are related to poor glycemic control [7-9]. Therefore, glycemic control is the principal therapeutic objective and fundamental way for the management of DM and its complications.

Previous studies have suggested that low-grade inflammation is associated with IR and it precedes the development of DM [10-13]. Low-grade inflammation is characterized by an up-regulation in acute-phase proteins and active inflammatory cytokine including C-reactive protein (CRP), tumor necrosis factor- $\alpha$ (TNF- $\alpha$ ), and interleukin-6 (IL-6), as well as an increase in infiltration of immune cells such as macrophages and

How to cite this article:

Kang M, Sohn SJ. Association between inflammatory markers and glycemic control in Korean Diabetic Patients. J Health Info Stat 2021;46(3):247-256. Doi: https://doi.org/10.21032/jhis.2021.46.3.247

(c) It is identical to the Creative Commons Attribution Non-Commercial License (https://creativecommons.org/licenses/by-nc/4.0) which permit sunrestricted non-commercial use, distribution and reproduction in any medium, provided the original work is properly cited.

(c) 2021 Journal of Health Informatics and Statistics 
T lymphocytes in insulin-dependent tissue $[14,15]$. Furthermore, lowgrade inflammation does not express structural tissue damage or loss of primary function [15]. Obesity, physical activity, smoking, eating habits, psychological stress, and infections that cause low-grade inflammatory conditions are also considered risk factors for DM [16].

Although several studies have evaluated the relationship between inflammatory markers and diabetes [10,17-21], few studies have evaluated the relationship between inflammatory markers and glycemic control in diabetic subject. In addition, there are few studies evaluating the association between inflammatory markers and glycemic control in diabetes subjects in Korea [22,23]. Furthermore, these Korean studies have limitations that cannot represent Koreans because the research subject is limited to certain region [22] or that only a limited range of inflammatory markers were used [23].

Therefore, this study investigated the relationship between inflammatory markers and glycemic control in diabetes subjects from 2007 to 2018 Korean National Health and Nutrition Examination (KNHANES) [1].

\section{METHODS}

\section{Study population}

This study was performed using 13-years of data from fourth (2007 to 2009), fifth (2011 to 2013), sixth (2013 to 2015), and seventh (2016 to 2018) KNHANES [1]. KNHANES is a cross-sectional survey designed to measure the health and nutritional status of the non-institutionalized Korean population. KNHANES is conducted by the Korea Centers for Disease Control and Prevention (KCDC) and features a health-related interview, a health examination, and a nutrition survey. At the first, 5,335 subjects (male; 2,543, female; 2,792, mean age; 65.28 years) who aged 19 to 80 years, diagnosed with diabetes by physician and taking oral hypoglycemic agents or insulin were selected from four KNHANES surveys (2007 to 2018). Among them, 880 subjects were excluded because of lack of information about covariates such as educational level, household income, smoking status, alcohol consumption, physical activity status, body mass index (BMI), triglycerides (TGs), CAD, stroke, hypertension, anemia, and hypercholesterolemia. A total of 269 subjects evidenced acute inflammation, as indicated by white blood cell (WBC) count higher than $10,000 / \mu \mathrm{L}$ and hsCRP levels over $10 \mathrm{mg} / \mathrm{L}$; these were excluded [24-27]. Finally, a total of 4,186 subjects (male 2,021, female 2,165, mean age 64.79 years) were analyzed. Since hsCRP measurements began in 2015 at KNAHANES, the analysis of the association between hsCRP and glycemic control was performed in 1,618 subjects (male 786, female 832 , mean age 65.87 years) from 2015 to 2018. All subjects provided written informed consent, and the Institutional Review Board (IRB) of the KCDC approved the study (IRB: 2007-02CON-04-P, 2008-04EXP-01-C, 2009-01CON-03-2C, 201002CON-21-C, 2011-02CON-06-C, 2012-01EXP-01-2C, 2013-07CON03-4C, 2013-12EXP-03-5C, and 2018-01-03-P-A).

\section{Definition of poor glycemic control}

Poor glycemic control was defined as level of HbAlc higher than 7.0\% as recommended by the American Diabetes Association [28]. When the $\mathrm{HbAlc}$ level was higher than 7.0\%, the risk of macro- and micro- vascular complications was significantly increased regardless of the main treatment [28], thus was selected as the cutoff value.

\section{Inflammatory markers}

The WBC count ware categorized into four groups by quartiles as follows: first quartile (Q1) lower than 5,439/ $\mu \mathrm{L}$; second quartile (Q2) 5,440

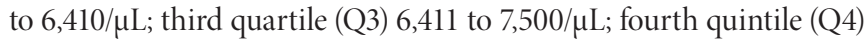
7,501 to $9,999 / \mu \mathrm{L}$. The hsCRP levels were also categorized into 4 groups by quartiles as follows: first quartile (Q1) lower than $0.4 \mathrm{mg} / \mathrm{L}$; second quartile (Q2) 0.41 to $0.65 \mathrm{mg} / \mathrm{L}$; third quartile (Q3) 0.66 to $1.29 \mathrm{mg} / \mathrm{L}$; fourth quintile (Q4) higher than $1.3 \mathrm{mg} / \mathrm{L}$.

\section{Covariates}

Data on demographic factors (age, marital status, household income, and educational level), lifestyle (smoking status, alcohol consumption, physical activity status, BMI, and TGs), and comorbidities (CAD, anemia, hypertension, stroke, and hypercholesterolemia) were included in possible confounders. Age, household income (the quartile of the monthly income for an individual), educational level (elementary school or less, middle or high school, and college or more), smoking status (never smoker, former smoker, and current smoker), alcohol consumption (consumed alcohol at least once monthly over the past year), physical activity status (push-ups, sit-ups, dumbbell or barbell lifts more than twice a week), CAD (diagnosis by a physician), stroke (diagnosis by a physician) and rheumatoid arthritis (diagnosis by a physician) were collected through KNHANES questionnaire. Anemia was defined based on WHO criteria [29]: level of serum hemoglobin lower than $13 \mathrm{~g} / \mathrm{dL}$ in males; $12 \mathrm{~g} / \mathrm{dL}$ in non-pregnant females; and $11 \mathrm{~g} / \mathrm{dL}$ in pregnant females. Hypertension 
was defined as a systolic blood pressure higher than $140 \mathrm{mmHg}$ or diastolic blood pressure higher than $90 \mathrm{mmHg}$ or currently taking anti-hypertensive medications. Hypercholesterolemia (level of total cholesterol higher than $240 \mathrm{mg} / \mathrm{dL}$ or current use of lipid-lowering medications) also collected. Weight and height were measured with subjects with no shoes and wearing light clothing. BMI was calculated by dividing the weight by the square of the height $\left(\mathrm{kg} / \mathrm{m}^{2}\right)$. Blood samples were taken from the antecubital vein after fasting at least 8 hours. Total cholesterol and TGs were measured Hitachi Automatic Analyzer 7600-210 (Hitachi/ Japan) through enzymatic method. HbAlc was measured by Tosoh G8 (Tosoh/Japan) through high performance liquid chromatography. WBC count were counted by XN-9000 (sysmex/Japan) through flow cytometry using semiconductor laser.

\section{Statistical analysis}

Categorical variables were described as observed numbers with percentages and were compared using the Pearson's chi-squared test. Continuous variables were given as means with standard deviations and were compared by analysis of variance. First quartile of inflammatory markers served as the reference category. A multiple logistic regression analysis was performed to evaluate the association between low-grade inflammation and glycemic control after adjusting for age, sex, educational level,

Table 1. Characteristics of subjects according to the WBC count quartile

\begin{tabular}{|c|c|c|c|c|c|c|}
\hline Characteristics & $\begin{array}{l}\text { Quartile } 1 \\
(<5,430 / \mu \mathrm{L})\end{array}$ & $\begin{array}{c}\text { Quartile } 2 \\
(5,431-6,410 / \mu \mathrm{L})\end{array}$ & $\begin{array}{c}\text { Quartile } 3 \\
(6,411-7,500 / \mu \mathrm{L})\end{array}$ & $\begin{array}{l}\text { Quartile } 4 \\
(\geq 7,501 / \mu \mathrm{L})\end{array}$ & Total & $p$-value \\
\hline n (\%) & $1,072(25.6)$ & $1,058(25.3)$ & $1,036(24.7)$ & $1,020(24.4)$ & $4,186(100.0)$ & \\
\hline Poor glycemic control & $455(42.4)$ & $555(52.5)$ & $580(56.0)$ & $619(60.7)$ & $2,209(52.8)$ & $<0.001$ \\
\hline Age (y) & $65.6 \pm 9.6$ & $65.1 \pm 9.5$ & $64.6 \pm 10.5$ & $63.7 \pm 10.8$ & $64.8 \pm 10.1$ & $<0.001$ \\
\hline Female & $626(58.4)$ & $565(53.4)$ & $494(47.7)$ & $480(47.1)$ & $2,165(51.7)$ & $<0.001$ \\
\hline Education & & & & & & 0.091 \\
\hline Elementary & $662(61.8)$ & $611(57.8)$ & $596(57.5)$ & $572(56.1)$ & $2,441(58.3)$ & \\
\hline High school & $243(22.7)$ & $242(22.9)$ & $249(24.0)$ & $265(26.0)$ & 999 (23.9) & \\
\hline College & $167(15.6)$ & 205 (19.4) & $191(18.4)$ & 183 (17.9) & $746(17.8)$ & \\
\hline House income & & & & & & 0.005 \\
\hline Low & $271(25.3)$ & $267(25.2)$ & $283(27.3)$ & $313(30.7)$ & $1,134(27.1)$ & \\
\hline Middle low & $283(26.4)$ & $247(23.3)$ & 289 (27.9) & $264(25.9)$ & $1,083(25.9)$ & \\
\hline Middle high & $256(23.9)$ & $252(23.8)$ & $235(22.7)$ & $228(22.4)$ & $971(23.2)$ & \\
\hline High & $262(24.4)$ & $292(27.6)$ & $229(22.1)$ & $215(21.1)$ & $998(23.8)$ & \\
\hline Marital status & & & & & & 0.124 \\
\hline Single & $12(1.1)$ & $9(0.9)$ & $19(1.8)$ & $23(2.3)$ & $63(1.5)$ & \\
\hline Married & $791(73.8)$ & $795(75.1)$ & $756(73.0)$ & $759(74.4)$ & $3,101(74.1)$ & \\
\hline Divorced/widowed/separated & $269(25.1)$ & $254(24.0)$ & $261(25.2)$ & $238(23.3)$ & $1,022(24.4)$ & \\
\hline Smoking & & & & & & $<0.001$ \\
\hline Never & $677(63.2)$ & $635(60.0)$ & $520(50.2)$ & $473(46.4)$ & 2,305 (55.1) & \\
\hline Past & $142(13.2)$ & $183(17.3)$ & $261(25.2)$ & $318(31.2)$ & 904 (21.6) & \\
\hline Current & $253(23.6)$ & $240(22.7)$ & 255 (24.6) & $229(22.5)$ & $977(23.3)$ & \\
\hline Alcohol consumption & $414(38.6)$ & $427(40.4)$ & $439(42.4)$ & $430(42.2)$ & $1,710(40.9)$ & 0.258 \\
\hline Physical activity & $100(9.3)$ & $96(9.1)$ & $86(8.3)$ & $70(6.9)$ & $352(8.4)$ & 0.174 \\
\hline $\mathrm{BMI}\left(\mathrm{kg} / \mathrm{m}^{2}\right)$ & $24.6 \pm 3.3$ & $25.0 \pm 3.1$ & $25.1 \pm 3.3$ & $25.5 \pm 3.6$ & $25.0 \pm 3.3$ & $<0.001$ \\
\hline Triglyceride & $140.4 \pm 110.3$ & $155.3 \pm 103.8$ & $168.1 \pm 106.0$ & $187.6 \pm 156.2$ & $162.5 \pm 121.9$ & $<0.001$ \\
\hline Prevalence of coronary artery disease & $94(8.8)$ & $94(8.9)$ & $94(9.1)$ & $81(7.9)$ & $363(8.7)$ & 0.808 \\
\hline Prevalence of stroke & $70(6.5)$ & $73(6.9)$ & $90(8.7)$ & $78(7.6)$ & $311(7.4)$ & 0.246 \\
\hline Prevalence of hypertension & $686(64.0)$ & $701(66.3)$ & $697(67.3)$ & $706(69.2)$ & $2,790(66.7)$ & 0.083 \\
\hline Prevalence of anemia & $222(20.7)$ & $141(13.3)$ & $133(12.8)$ & $136(13.3)$ & $632(15.1)$ & $<0.001$ \\
\hline Prevalence of hypercholesterolemia & $357(33.3)$ & $419(39.6)$ & $374(36.1)$ & $374(36.7)$ & $1,524(36.4)$ & 0.027 \\
\hline Prevalence of rheumatoid arthritis & $42(3.9)$ & $33(3.1)$ & $39(3.8)$ & $25(2.5)$ & $139(3.3)$ & 0.225 \\
\hline
\end{tabular}

WBC, white blood cell; BMI, body mass index.

Values are expressed as mean \pm standard deviation or number (\%).

$p$-values were calculated from the analysis of variance for continuous variables and the Pearson's chi-square test for categorical variables. 
household income, marital status, smoking status, alcohol consumption, physical activity, BMI, TGs, CAD, prevalence of stroke, prevalence of hypertension, prevalence of anemia, and prevalence of hypercholesterolemia, and the results are presented as odds ratios (OR) and corresponding 95\% confidence intervals (CI). Predictive margins of inflammatory markers were used assessing the linear relationship between low-grade inflammation and glycemic control. To assess the effect modification by sex, age, and anemia, stratified analyzes were performed. Statistical significance was set at level of $p$-value lower than 0.05 . All statistical analyses were performed using Stata ver. 15.0 software (Stata Corp., College Station, TX, USA).

\section{RESULTS}

The general characteristics of subject according to the quartile of WBC count are shown in Table 1. Of the 4,186 subject, 1,072 (25.6\%) were in the first quartile, 1,058 (25.3\%) in the second quartile, 1,036 (24.7\%) in the third quartile and 1,020 (24.4\%) in the fourth quartile. The percentage of poor glycemic control were as follows: first quartile $42.4 \%$, second $52.5 \%$, third 56.0 , fourth $60.7 \%$. Overall, $52.8 \%$ of subjects exhibited poor glycemic control. The overall proportion of females was 51.7\%, this decreased as the quartile of WBC count increased. The average age was 64.8 years: 65.6 for the first quartile, 65.1 for the second, 64.6 for the third,

Table 2. Characteristics of subjects according to the hsCRP quartile

\begin{tabular}{|c|c|c|c|c|c|c|}
\hline Characteristics & $\begin{array}{c}\text { Quartile } 1 \\
\text { (<0.4 mg/L) }\end{array}$ & $\begin{array}{c}\text { Quartile } 2 \\
(0.41-0.65 \mathrm{mg} / \mathrm{L})\end{array}$ & $\begin{array}{c}\text { Quartile } 3 \\
(0.66-1.29 \mathrm{mg} / \mathrm{L})\end{array}$ & $\begin{array}{l}\text { Quartile } 4 \\
\text { ( } \geq 1.3 \mathrm{mg} / \mathrm{L})\end{array}$ & Total & $p$-value \\
\hline n (\%) & $480(29.7)$ & $364(22.5)$ & $399(24.7)$ & $375(23.2)$ & $1,618(100.0)$ & \\
\hline Poor glycemic control & $193(40.2)$ & $171(47.0)$ & $219(54.9)$ & $207(55.2)$ & $790(48.8)$ & $<0.001$ \\
\hline Age (y) & $66.6 \pm 9.5$ & $64.9 \pm 10.7$ & $65.8 \pm 10.3$ & $66.0 \pm 10.5$ & $65.9 \pm 10.2$ & 0.134 \\
\hline Female & $247(51.5)$ & $174(47.8)$ & $217(54.4)$ & $194(51.7)$ & $832(51.4)$ & 0.344 \\
\hline Education & & & & & & 0.187 \\
\hline Elementary & $280(58.3)$ & $193(53.0)$ & $243(60.9)$ & $225(60.0)$ & $941(58.2)$ & \\
\hline High school & $122(25.4)$ & 115 (31.6) & $100(25.1)$ & $88(23.5)$ & $425(26.3)$ & \\
\hline College & $78(16.3)$ & $56(15.4)$ & $56(14.0)$ & $62(16.5)$ & $252(15.6)$ & \\
\hline House income & & & & & & 0.333 \\
\hline Low & $124(25.8)$ & $94(25.8)$ & $109(27.3)$ & $120(32.0)$ & $447(27.6)$ & \\
\hline Middle low & $143(29.8)$ & $88(24.2)$ & $106(26.6)$ & $87(23.2)$ & $424(26.2)$ & \\
\hline Middle high & $111(23.1)$ & $93(25.5)$ & $89(22.3)$ & $88(23.5)$ & $381(23.5)$ & \\
\hline High & $102(21.3)$ & $89(24.5)$ & $95(23.8)$ & $80(21.3)$ & $366(22.6)$ & \\
\hline Marital status & & & & & & 0.062 \\
\hline Single & $5(1.0)$ & $6(1.6)$ & $14(3.5)$ & $7(1.9)$ & $32(2.0)$ & \\
\hline Married & $363(75.6)$ & $265(72.8)$ & $280(70.2)$ & $257(68.5)$ & $1,165(72.0)$ & \\
\hline Divorced/widowed/separated & $112(23.3)$ & $93(25.5)$ & $105(26.3)$ & $111(29.6)$ & $421(26.0)$ & \\
\hline Smoking & & & & & & 0.621 \\
\hline Never & $275(57.3)$ & $202(55.5)$ & $235(58.9)$ & $199(53.1)$ & $911(56.3)$ & \\
\hline Past & $66(13.8)$ & $61(16.8)$ & $54(13.5)$ & $58(15.5)$ & $239(14.8)$ & \\
\hline Current & $139(29.0)$ & $101(27.7)$ & $110(27.6)$ & $118(31.5)$ & $468(28.9)$ & \\
\hline Alcohol consumption & $202(42.1)$ & $171(47.0)$ & $162(40.6)$ & $147(39.2)$ & $682(42.2)$ & 0.157 \\
\hline Physical activity & $49(10.2)$ & $33(9.1)$ & $32(8.0)$ & $30(8.0)$ & $144(8.9)$ & 0.619 \\
\hline $\mathrm{BMI}\left(\mathrm{kg} / \mathrm{m}^{2}\right)$ & $24.1 \pm 2.7$ & $25.1 \pm 3.1$ & $25.6 \pm 3.4$ & $26.1 \pm 3.7$ & $25.1 \pm 3.3$ & $<0.001$ \\
\hline Triglyceride & $131.4 \pm 74.4$ & $159.9 \pm 101.2$ & $170.6 \pm 132.3$ & $170.0 \pm 127.3$ & $156.5 \pm 110.8$ & $<0.001$ \\
\hline Prevalence of coronary artery disease & $49(10.2)$ & $24(6.6)$ & $29(7.3)$ & $31(8.3)$ & $133(8.2)$ & 0.234 \\
\hline Prevalence of stroke & $32(6.7)$ & $24(6.6)$ & $25(6.3)$ & $38(10.1)$ & $119(7.4)$ & 0.134 \\
\hline Prevalence of hypertension & $292(60.8)$ & $231(63.5)$ & $293(73.4)$ & $275(73.3)$ & $1,091(67.4)$ & $<0.001$ \\
\hline Prevalence of anemia & 94 (19.6) & $49(13.5)$ & $53(13.3)$ & $59(15.7)$ & $255(15.8)$ & 0.035 \\
\hline Prevalence of hypercholesterolemia & $236(49.2)$ & $155(42.6)$ & $166(41.6)$ & $160(42.7)$ & $717(44.3)$ & 0.085 \\
\hline Prevalence of rheumatoid arthritis & $15(3.1)$ & $11(3.0)$ & $8(2.0)$ & $14(3.7)$ & $48(3.0)$ & 0.553 \\
\hline
\end{tabular}

hsCRP, high-sensitivity C-reactive protein; BMI, body mass index.

Values are expressed as mean \pm standard deviation or number (\%).

$p$-values were calculated from the analysis of variance for continuous variables and the Pearson's chi-square test for categorical variables. 
and 63.7 for the fourth. In terms of household income, the proportions of low-income subjects were $25.3 \%$ in the first quartile, $25.2 \%$ in the second, $27.3 \%$ in the third, and $30.7 \%$ in the fourth. The proportions of former smokers gradually increased from $13.2 \%$ in the first quartile, to $17.3 \%$ in the second, to $25.2 \%$ in the third, and to $31.2 \%$ in the fourth. The average BMI of the subjects was $25.0 \mathrm{~kg} / \mathrm{m}^{2}$ and increased as the quartile of the WBC count increased: first quartile $24.6 \mathrm{~kg} / \mathrm{m}^{2}$, second quartile $25.0 \mathrm{~kg} / \mathrm{m}^{2}$, third quartile $25.1 \mathrm{~kg} / \mathrm{m}^{2}$, and fourth $25.5 \mathrm{~kg} / \mathrm{m}^{2}$. The mean value of TGs was $162.5 \mathrm{mg} / \mathrm{dL}$ and as the increased by quartile of WBC count: first quartile $140.4 \mathrm{mg} / \mathrm{dL}$, second $155.3 \mathrm{mg} / \mathrm{dL}$, third $168.1 \mathrm{mg} / \mathrm{dL}$, and fourth $187.6 \mathrm{mg} / \mathrm{dL}$. The prevalence of anemia increased as the quartile of WBC count increased. The prevalence of hypercholesterolemia was the highest (39.6\%) in the second quartile of WBC count (Table 1).

The general characteristics of subject according to the quartile of hsCRP are shown in Table 2. Of the 1,618 subjects, 480 (29.7\%) were in the first quartile, $36.4(22.5 \%)$ in the second, 399 (24.7\%) in the third, and 97.5 (23.2\%) in the fourth. The proportion of poor glycemic control were as follows: first quartile $40.2 \%$, second $47.0 \%$, third 54.9 , and fourth $55.2 \%$. Overall, $48.8 \%$ subjects had poor glycemic control. The average BMI was $25.1 \mathrm{~kg} / \mathrm{m}^{2}$ and increased with quartile of hsCRP increased: first quartile $24.1 \mathrm{~kg} / \mathrm{m}^{2}$, second $25.1 \mathrm{~kg} / \mathrm{m}^{2}$, third $25.6 \mathrm{~kg} / \mathrm{m}^{2}$, and quartile $26.1 \mathrm{~kg} / \mathrm{m}^{2}$. The mean value of TGs was $156.5 \mathrm{mg} / \mathrm{dL}$ and as the increased by quartile of hsCRP: first quartile $131.4 \mathrm{mg} / \mathrm{dL}$, second $159.9 \mathrm{mg} / \mathrm{dL}$, third 170.6 $\mathrm{mg} / \mathrm{dL}$, and fourth $170.1 \mathrm{mg} / \mathrm{dL}$.

The prevalence of hypertension increased as the quartile of hsCRP increased. In case of Anemia, the prevalence rate was the highest at 19.6\% in the first quartile of hsCRP (Table 2). The ORs of quartiles of inflammatory markers for poor glycemic control are shown in Table 3. There was a linear relationship between low-grade inflammation and glycemic control. In terms of WBC count, compared to the first quartile, the OR for poor glycemic control was 1.50 (95\% CI: 1.26-1.78) in the second, 1.72 (95\% CI: 1.45-2.05) in the third, and 2.09 (95\% CI: 1.76-2.49) in the fourth. Even after adjusting for potential confounders, the association remained significant; the adjusted OR for the second quartile was 1.50 (95\% CI: 1.26-1.78), 1.71 (95\% CI: 1.43-2.05) for the third, 2.00 (95\% CI: 1.67-2.40) for the fourth. The association between hsCRP level and poor glycemic control differed slightly from that described above. Compared to the first quartile of hsCRP, the OR for poor glycemic control was $1.32(95 \%$ CI: 1.00-1.73) for the second, 1.81 (95\% CI: 1.38-2.37) for the third, and 1.81 (95\% CI: 1.39-2.41) for the fourth, but was significant only for the third and fourth quartiles. After adjusting for potential confounders, this association was slightly attenuated but still maintained; the adjusted OR for the second quartile was 1.15 (95\% CI: 0.87-1.53), 1.59 (95\% CI: 1.20 2.11) for the third, and 1.59 (95\% CI: 1.19-2.12) for the fourth (Table 3).

Tables 4 show the stratified analyses by sex, age, and the prevalence of anemia of the association between inflammatory markers and poor glycemic control. In the stratified analysis by sex, the association between inflammatory markers and poor glycemic control was evident in female than in male but there was no statistically significant interaction $(p$ for interaction of WBC count; 0.122 , $p$ for interaction of hsCRP; 0.450).

In the age-stratified analysis, the association between inflammatory markers and poor glycemic control was evident in subjects under 65 years

Table 3. Association between inflammation markers and the poor glycemic control

\begin{tabular}{|c|c|c|c|c|}
\hline \multirow{2}{*}{$\begin{array}{l}\text { Variables } \\
\text { Category of Inflammation markers }\end{array}$} & \multicolumn{2}{|c|}{ Unadjusted } & \multicolumn{2}{|c|}{ Adjusted } \\
\hline & OR $(95 \% \mathrm{Cl})$ & $p$-value & OR $(95 \% \mathrm{Cl})$ & $p$-value \\
\hline \multicolumn{5}{|l|}{ WBC counts $(\mu \mathrm{L})$} \\
\hline Quartile $2(5,431-6,410)$ & $1.50(1.26-1.78)$ & $<0.001$ & $1.50(1.26-1.78)$ & $<0.001$ \\
\hline Quartile $3(6,411-7,500)$ & $1.72(1.45-2.05)$ & $<0.001$ & $1.71(1.43-2.05)$ & $<0.001$ \\
\hline Quartile 4 ( $\geq 7,501)$ & $2.09(1.76-2.49)$ & $<0.001$ & $2.00(1.67-2.40)$ & $<0.001$ \\
\hline Quartile $1(<0.40)$ & 1 (reference) & - & 1 (reference) & - \\
\hline Quartile $2(0.41-0.60)$ & $1.32(1.00-1.73)$ & 0.049 & $1.15(0.87-1.53)$ & 0.325 \\
\hline Quartile 3 (0.61-1.20) & $1.81(1.38-2.37)$ & $<0.001$ & $1.59(1.20-2.11)$ & 0.001 \\
\hline Quartile 4 ( $\geq 1.21$ ) & $1.83(1.39-2.41)$ & $<0.001$ & $1.59(1.19-2.12)$ & 0.002 \\
\hline
\end{tabular}

WBC, white blood cell; hsCRP, high-sensitivity C-reactivity protein; OR, odds ratio; Cl, confidence interval.

Adjusted for age, sex, educational level, marital status, household income, smoking status, alcohol consumption, physical activity, body mass index, triglyceride, and comorbidities (coronary artery disease, stroke, hypertension, anemia, hypercholesterolemia, rheumatoid arthritis). 
Table 4. Stratified analysis of the association between inflammation markers and the poor glycemic control

\begin{tabular}{|c|c|c|c|c|c|c|c|}
\hline \multirow{2}{*}{ Variables } & & \multirow{2}{*}{$\begin{array}{l}\text { Inflammation } \\
\text { markers category }\end{array}$} & \multicolumn{2}{|c|}{ Male } & \multicolumn{2}{|c|}{ Female } & \multirow{2}{*}{$\begin{array}{c}p \text { for } \\
\text { interaction }\end{array}$} \\
\hline & & & OR $(95 \% \mathrm{Cl})$ & $p$-value & OR $(95 \% \mathrm{Cl})$ & $p$-value & \\
\hline \multirow[t]{7}{*}{ Sex } & WBC counts $(\mu \mathrm{L})$ & Quartile $1(<5,430)$ & 1 (reference) & - & 1 (reference) & - & 0.122 \\
\hline & & Quartile $3(6,411-7,500)$ & $1.61(1.24-2.09)$ & $<0.001$ & $1.71(1.34-2.19)$ & $<0.001$ & \\
\hline & & Quartile 4 ( $\geq 7,501)$ & $1.62(1.24-2.11)$ & $<0.001$ & $2.39(1.85-3.09)$ & $<0.001$ & \\
\hline & $\mathrm{hsCRP}(\mathrm{mg} / \mathrm{L})$ & Quartile $1(<0.40)$ & 1 (reference) & - & 1 (reference) & - & 0.450 \\
\hline & & Quartile 3 (0.66-1.29) & $1.39(0.92-2.11)$ & 0.117 & $1.92(1.3-2.84)$ & 0.001 & \\
\hline & & Quartile 4 ( $\geq 1.30$ ) & $1.27(0.83-1.93)$ & 0.267 & $2.00(1.33-3.01)$ & 0.001 & \\
\hline & & & \multicolumn{2}{|c|}{ Age under 65 years } & \multicolumn{2}{|c|}{ Age over 65 years } & \\
\hline \multirow[t]{6}{*}{ Age } & WBC counts $(\mu \mathrm{L})$ & Quartile $1(<5,430)$ & 1 (reference) & - & 1 (reference) & - & 0.939 \\
\hline & & Quartile $2(5,431-6,410)$ & $1.53(1.17-2)$ & 0.002 & $1.47(1.16-1.85)$ & 0.001 & \\
\hline & & Quartile $2(0.41-0.65)$ & $2.18(1.39-3.41)$ & 0.001 & $0.74(0.5-1.08)$ & 0.120 & \\
\hline & & Quartile 3 (0.66-1.29) & $2.26(1.43-3.57)$ & $<0.001$ & $1.35(0.93-1.95)$ & 0.110 & \\
\hline & & Quartile 4 ( $\geq 1.30)$ & $2.42(1.48-3.94)$ & $<0.001$ & $1.32(0.91-1.91)$ & 0.137 & \\
\hline & & & \multicolumn{2}{|c|}{ With anemia } & \multicolumn{2}{|c|}{ Without anemia } & \\
\hline \multirow[t]{6}{*}{ Anemia } & WBC counts $(\mu \mathrm{L})$ & Quartile $1(<5,430)$ & 1 (reference) & - & 1 (reference) & - & 0.145 \\
\hline & & Quartile $2(5,431-6,410)$ & $1.42(0.91-2.21)$ & 0.127 & $1.49(1.23-1.81)$ & $<0.001$ & \\
\hline & & Quartile $3(6,411-7,500)$ & $1.88(1.18-2.98)$ & 0.008 & $1.67(1.38-2.03)$ & $<0.001$ & \\
\hline & & Quartile $4(\geq 7,501)$ & $3.15(1.95-5.08)$ & $<0.001$ & $1.86(1.52-2.27)$ & $<0.001$ & \\
\hline & $\mathrm{hsCRP}(\mathrm{mg} / \mathrm{L})$ & Quartile $1(<0.40)$ & 1 (reference) & - & 1 (reference) & - & 0.544 \\
\hline & & Quartile $2(0.41-0.65)$ & $0.76(0.35-1.63)$ & 0.476 & $1.27(0.93-1.74)$ & 0.132 & \\
\hline
\end{tabular}

WBC, white blood cell; hsCRP, high-sensitivity $\mathrm{C}$ reactive protein; OR, odds ratio; $\mathrm{Cl}$, confidence interval.

Adjusted for age, sex, educational level, marital status, household income, smoking status, alcohol consumption, physical activity, body mass index, triglyceride, and comorbidities (coronary artery disease, stroke, hypertension, anemia, hypercholesterolemia, rheumatoid arthritis).

of age than older, and there was a statistically significant interaction in $\operatorname{hsCRP}(p=0.007)$ but not in WBC count $(p=0.939)$. In terms of the hsCRP level, the adjusted OR of subjects under 65 years of age for second quartile was 2.18 (95\% CI: 1.39-3.41), 2.26 (95\% CI: 1.43-3.57) for third, and 2.41 (95\% CI: 1.48-3.94) for fourth. In subjects of over 65 years of age, the adjusted OR for second quartile was 0.74 (95\% CI: 0.50-1.08), 1.35 (95\% CI: 0.93-1.95) for third, and 1.32 (95\% CI: 0.91-1.92) for fourth.

In terms of anemia, the association between the WBC count and poor glycemic control was more evident in subjects without than with anemia, whereas the association between hsCRP level and poor glycemic control was more apparent in subjects with than without anemia but was not statistically significant. There was no statistically significant interaction ( $p$ for interaction of WBC count; $0.145, p$ for interaction of hsCRP; 0.544 )

\section{DISCUSSION}

This cross-sectional study evaluated the relationship between low-grade inflammation and poor glycemic control in a nationally representative sample of Korean patients with diabetes mellitus (DM). The WBC counts quartiles and hsCRP quartiles of this study were higher than those of previous studies targeting healthy subjects or subjects with diseases such as COPD [23,30-33]. There were significant linear associations between inflammatory markers and poor glycemic control even after for adjusting potential confounders including demographic factors, lifestyle factors, and comorbidities. In age-stratified analyses, the association between inflammatory markers and poor glycemic control was more evident in younger (less than 65 years) than in the older subjects. 
Previous studies have evaluated the relationship between low-grade inflammation and glycemic control. Similar to the result of this study, several previous studies reported a positive association between inflammatory markers and glycemic control [22,34-37]. Sefil et al. [34] studied 71 T2 DM subject and Oh et al. [22], 90 T2 DM subject, those exhibiting poor glycemic control group had higher WBC counts and neutrophil lymphocyte ratio (NLR) than others. In a study using 1,614 NHANES subjects of the United States (U.S.), high HbAlc was significantly associated with high CRP in diabetic subjects [35]. According to a study by Huffman et al. [36] of 182 T2DM subjects, when the subjects were divided into three groups according to the HbAlc value, the group with the highest $\mathrm{HbAlc}$ had a CRP value three-fold that group with the lowest HbAlc. De Rekeneire et al. [37] studied diabetic subjects aged 70-79 years in the U.S.; those evidencing poor glycemic control had higher levels of CRP with an OR of 1.17 (95\% CI: 1.04-1.32). However, some studies did not find any statistically significant association between $\mathrm{HbAlc}$ and WBC count $[38,39]$. In the cross-sectional study of Milosevic et al. [38], correlation were evident between level of HbAlc, platelet dry mass distribution width, and red blood cell distribution width, but not between WBC count and glycemic control. Nada et al. [39] found a positive correlation between WBC count and duration of DM was reported, but no significant correlation between fasting plasma glucose and level of HbAlc.

The pathophysiological mechanism of the association between inflammation and glycemic control remains unclear, but the following explanation may be possible. The increased WBC and CRP levels caused by inflammation enhance the release various cytokines and growth factors such as IL-6, tumor necrosis factor, and transforming growth factor$\beta 1$ [40-43]. Increased cytokines interfere with the cell's insulin receptors and it leads to IR and endothelial dysfunction [44]. Usually IR is accompanied by inflammation and adipose tissue inflammation [45]. IR again leads to inflammation and enters a vicious cycle [46]. As a result, the vicious cycle induced by insulin resistance and inflammation adversely affects glycemic control.

Ha et al. [47] found an inverse linear relationship between BMI and age at diabetic subjects, and this study also showed that subjects under 65 years of age had a lower average BMI than older subjects. These BMI differences might be a possible explanation for the association between high CRP and poor glycemic control in subjects under 65 years of age. The IL-6 protein is significantly increased in adipocytes of obese sub- jects $[48,49]$, and the increased IL- 6 stimulates CRP secretion by hepatocytes [50]. CRP secreted from hepatocytes again stimulates the excretion of IL- 6 from monocytes [42]. Increased IL-6 triggers cytokine excretion and increased cytokine disrupts insulin receptors, leading to IR and endothelial dysfunction [44]. This induced IR and endothelial dysfunction can lead to poor glycemic control in subjects under the age of 65 .

Although this study has the advantage of a large-scale study conducted on a nationally representative sample, it also had certain limitations. First, lack of data on other inflammatory markers including the erythrocyte sedimentation rate (ESR), IL-6 and fibrinogen levels. However, the WBC count and the hsCRP level, traditional inflammatory markers, are routinely used in clinical practice and health screening, and have also been reported to predict the progression of DM in several studies $[10,51,52]$. Thus, WBC count and hsCRP, like other markers, can reflect inflammation well. Second, long-term clinical outcome should be monitored according to levels of WBC count and CRP in Korean diabetic patients. Third, degree of poor glycemic control and duration of DM could not be analyzed in this study. Forth, given the cross-sectional study design, a causal relationship between low-grade inflammation and glycemic control cannot be inferred. Therefore, further research is required to establish the causal relation and the mechanisms whereby inflammation may compromise glycemic control in diabetes patients.

\section{CONCLUSION}

Using the 2007-2018 KNAHNES data representing Korea, the associations between inflammatory markers and poor glycemic control in diabetic subject was evaluated through multivariate logistic regression after adjusting for potential confounders including demographic factors, lifestyle factors, and comorbidities. As a result, there was a statistically significant linear relationships between both inflammatory markers and poor glycemic control. In addition, stratified analyses revealed a statistically significant effect of age on the relationship between the hsCRP level and poor glycemic control. These results indicate a significant association between inflammation and poor glycemic control in a nationally representative sample of Korean diabetes patients. Further research is required to establish the causal relationships between inflammatory markers and poor glycemic control and the underlying mechanism, and such studies could be of significant implication for the diabetes treatments in Korea. 


\section{REFERENCES}

1. Kweon S, Kim Y, Jang M, Kim Y, Kim K, Choi S, et al. Data resource profile: the Korea National Health and Nutrition Examination Survey (KNHANES). Int J Epidemiol 2014;43(1):69-77. DOI: 10.1093/ije/ dyt228

2. Indicators O. Health at a Glance. Paris: OECD Publishing; 2015.

3. Bommer C, Sagalova V, Heesemann E, Manne-Goehler J, Atun R, Bärnighausen T, et al. Global economic burden of diabetes in adults: projections from 2015 to 2030. Diabetes Care 2018;41(5):963-970. DOI: $10.2337 / \mathrm{dc} 17-1962$

4. Park JH, Lee YE. Effects of exercise on glycemic control in type 2 diabetes mellitus in Koreans: the fifth Korea National Health and Nutrition Examination Survey (KNHANES V). J Phys Ther Sci 2015;27(11): 3559-3564. DOI: 10.1589/jpts.27.3559

5. Deshpande AD, Harris-Hayes M, Schootman M. Epidemiology of diabetes and diabetes-related complications. Phys Ther 2008;88(11): 1254-1264. DOI: 10.2522/ptj.20080020

6. de Morais PK, Sales MM, de Almeida JA, Motta-Santos D, de Sousa CV, Simoes HG. Effects of aerobic exercise intensity on 24-h ambulatory blood pressure in individuals with type 2 diabetes and prehypertension. J Phys Ther Sci 2015;27(1):51-56. DOI: 10.1589/jpts.27.51

7. Alsenany S, Al Saif A. Incidence of diabetes mellitus type 2 complications among Saudi adult patients at primary health care center. J Phys Ther Sci 2015;27(6):1727-1730. DOI: 10.1589/jpts.27.1727

8. Fasil A, Biadgo B, Abebe M. Glycemic control and diabetes complications among diabetes mellitus patients attending at University of Gondar Hospital, Northwest Ethiopia. Diabetes Metab Syndr Obes 2018; 12:75-83. DOI: 10.2147/DMSO.S185614

9. Stolar M. Glycemic control and complications in type 2 diabetes mellitus. Am J Med 2010;123(3 Suppl):S3-11. DOI: 10.1016/j.amjmed. 2009.12.004

10. Vozarova B, Weyer C, Lindsay RS, Pratley RE, Bogardus C, Tataranni PA. High white blood cell count is associated with a worsening of insulin sensitivity and predicts the development of type 2 diabetes. Diabetes 2002;51(2):455-461. DOI: 10.2337/diabetes.51.2.455

11. Bastard JP, Maachi M, Lagathu C, Kim MJ, Caron M, Vidal H, et al. Recent advances in the relationship between obesity, inflammation, and insulin resistance. Eur Cytokine Netw 2006;17(1):4-12.

12. Pradhan AD, Cook NR, Buring JE, Manson JE, Ridker PM. C-reactive protein is independently associated with fasting insulin in nondiabetic women. Arterioscler Thromb Vasc Biol 2003;23(4):650-655. DOI: 10.1161/01.ATV.0000065636.15310.9C

13. Shoelson SE, Lee J, Goldfine AB. Inflammation and insulin resistance. J Clin Invest 2006;116(7):1793-1801. DOI: 10.1172/JCI29069

14. van Greevenbroek MM, Schalkwijk CG, Stehouwer CD. Obesity-associated low-grade inflammation in type 2 diabetes mellitus: causes and consequences. Neth J Med 2013;71(4):174-187.

15. León-Pedroza JI, González-Tapia LA, del Olmo-Gil E, CastellanosRodríguez D, Escobedo G, González-Chávez A. Low-grade systemic inflammation and the development of metabolic diseases: from the molecular evidence to the clinical practice. Cir Cir 2015;83(6):543551. DOI: 10.1016/j.circir.2015.05.041

16. Pitsavos C, Tampourlou M, Panagiotakos DB, Skoumas Y, Chrysohoou C, Nomikos T, et al. Association between low-grade systemic inflammation and type 2 diabetes mellitus among men and women from the ATTICA study. Rev Diabet Stud 2007;4(2):98-104. DOI: 10.1900/RDS.2007.4.98

17. Pradhan AD, Manson JE, Rifai N, Buring JE, Ridker PM. C-reactive protein, interleukin 6 , and risk of developing type 2 diabetes mellitus. JAMA 2001;286(3):327-334. DOI: 10.1001/jama.286.3.327

18. Liu S, Hempe JM, McCarter RJ, Li S, Fonseca VA. Association between inflammation and biological variation in hemoglobin Alc in U.S. nondiabetic adults. J Clin Endocrinol Metab 2015;100(6):2364-2371. DOI: 10.1210/jc.2014-4454

19. Kizilgul M, Sencar E, Uçan B, Beysel S, Ozcelik O, Ozbek M, et al. Components of the complete blood count in type 2 diabetes mellitus with inadequate glycemic control. Dicle Tip Dergisi 2018;45(2):113-120. DOI: $10.5798 /$ dicletip.410811

20. Duncan BB, Schmidt MI, Pankow JS, Ballantyne CM, Couper D, Vigo A, et al. Low-grade systemic inflammation and the development of type 2 diabetes: the atherosclerosis risk in communities study. Diabetes 2003;52(7):1799-1805. DOI: 10.2337/diabetes.52.7.1799

21. Barzilay JI, Abraham L, Heckbert SR, Cushman M, Kuller LH, Resnick HE, et al. The relation of markers of inflammation to the development of glucose disorders in the elderly: the Cardiovascular Health Study. Diabetes 2001;50(10):2384-2389. DOI: 10.2337/diabetes.50.10.2384

22. Oh Y, Kwon GC, Koo SH, Kim J. Association between glycemic control and hematologic indices in type 2 diabetic patients. Lab Med Online 2016;6(3):134-139. DOI:10.3343/lmo.2016.6.3.134 
23. Hong JW, Noh JH, Kim DJ. Association between white blood cell counts within normal range and hemoglobin Alc in a Korean population. Endocrinol Metab (Seoul) 2018;33(1):79-87. DOI: 10.3803/EnM.2018. 33.1.79

24. Bentley DW, Bradley S, High K, Schoenbaum S, Taler G, Yoshikawa TT. Practice guideline for evaluation of fever and infection in long-term care facilities. J Am Geriatr Soc 2001;49(2):210-222. DOI: 10.1046/ j.1532-5415.2001.49999.x

25. Kanmani S, Kwon M, Shin MK, Kim MK. Association of C-reactive protein with risk of developing type 2 diabetes mellitus, and role of obesity and hypertension: A large population-based Korean cohort study. Sci Rep 2019;9(1):4573. DOI: 10.1038/s41598-019-40987-8

26. Zalli A, Jovanova O, Hoogendijk W, Tiemeier H, Carvalho L. Lowgrade inflammation predicts persistence of depressive symptoms. Psychopharmacology (Berl) 2016;233(9):1669-1678. DOI: 10.1007/ s00213-015-3919-9

27. George EL, Panos A. Does a high WBC count signal infection? Nursing 2005;35(1):20-21. DOI: 10.1097/00152193-200501000-00014

28. American Diabetes Association. Diagnosis and classification of diabetes mellitus. Diabetes Care 2014;37(Suppl 1):S81-90. DOI: 10.2337/ dc14-S081

29. World Health Organization. The global prevalence of anaemia in 2011. Geneva: World Health Organization; 2015.

30. Lee YJ, Lee JW, Kim JK, Lee JH, Kim JH, Kwon KY, et al. Elevated white blood cell count is associated with arterial stiffness. Nutr Metab Cardiovasc Dis 2009;19(1):3-7. DOI: 10.1016/j.numecd.2008.02.003

31. Lin F, Chen Y, Wan M, Chen W, Jia W. High-sensitivity C-reactive protein as an indicator of ischemic stroke in patients with isolated acute vestibular syndrome: Retrospective observational study. Medicine (Baltimore) 2019;98(48):e18097. DOI: 10.1097/MD.0000000000018097

32. Koo HK, Kang HK, Song P, Park HK, Lee SS, Jung H. Systemic white blood cell count as a biomarker associated with severity of chronic obstructive lung disease. Tuberc Respir Dis (Seoul) 2017;80(3):304-310. DOI: 10.4046/trd.2017.80.3.304

33. Zhang H, Yang Z, Zhang W, Niu Y, Li X, Qin L, et al. White blood cell subtypes and risk of type 2 diabetes. J Diabetes Complications 2017; 31(1):31-37. DOI: 10.1016/j.jdiacomp.2016.10.029

34. Sefil F, Ulutas KT, Dokuyucu R, Sumbul AT, Yengil E, Yagiz AE, et al. Investigation of neutrophil lymphocyte ratio and blood glucose regulation in patients with type 2 diabetes mellitus. J Int Med Res 2014;42(2):

\section{1-588. DOI: 10.1177/0300060513516944}

35. King DE, Mainous AG, Buchanan TA, Pearson WS. C-reactive protein and glycemic control in adults with diabetes. Diabetes Care 2003;26(5): 1535-1539. DOI: 10.2337/diacare.26.5.1535

36. Huffman FG, Zarini G, Swink M, Gomez GP. Relationship between glycemic control and C-reactive protein in Cuban-Americans with type 2 diabetes mellitus. The FASEB Journal 2008;22(51):1098.3-1098.3. DOI: 10.1096/fasebj.22.1_supplement.1098.3

37. de Rekeneire N, Peila R, Ding J, Colbert LH, Visser M, Shorr RI, et al. Diabetes, hyperglycemia, and inflammation in older individuals: the health, aging and body composition study. Diabetes Care 2006;29(8): 1902-1908. DOI: 10.2337/dc05-2327

38. Milosevic D, Panin VL. Relationship between hematological parameters and glycemic control in type 2 diabetes mellitus patients. J Med Biochem 2019;38(2):164-171. DOI: 10.2478/jomb-2018-0021

39. Nada AM. Red cell distribution width in type 2 diabetic patients. Diabetes Metab Syndr Obes 2015;8:525-533. DOI: 10.2147/DMSO. S85318

40. Klein NJ, Shennan GI, Heyderman RS, Levin M. Alteration in glycosaminoglycan metabolism and surface charge on human umbilical vein endothelial cells induced by cytokines, endotoxin and neutrophils. J Cell Sci 1992;102(Pt 4):821-832.

41. Pickup JC, Mattock MB, Chusney GD, Burt D. NIDDM as a disease of the innate immune system: association of acute-phase reactants and interleukin-6 with metabolic syndrome X. Diabetologia 1997;40(11): 1286-1292. DOI: 10.1007/s001250050822

42. Blake GJ, Ridker PM. Tumour necrosis factor-alpha, inflammatory biomarkers, and atherogenesis. Eur Heart J 2002;23(5):345-347. DOI: 10.1053/euhj.2001.2905

43. Chen L, Chen R, Wang H, Liang F. Mechanisms linking inflammation to insulin resistance. Int J Endocrinol 2015;2015:508409. DOI: 10. $1155 / 2015 / 508409$

44. Ross R. Atherosclerosis-an inflammatory disease. N Engl J Med 1999; 340(2):115-126. DOI: 10.1056/NEJM199901143400207

45. Wieser V, Moschen AR, Tilg H. Inflammation, cytokines and insulin resistance: a clinical perspective. Arch Immunol Ther Exp (Warsz) 2013;61(2):119-125. DOI: 10.1007/s00005-012-0210-1

46. de Luca C, Olefsky JM. Inflammation and insulin resistance. FEBS Lett 2008;582(1):97-105. DOI: 10.1016/j.febslet.2007.11.057

47. Ha KH, Kim DJ. Trends in the Diabetes Epidemic in Korea. Endocri- 
nol Metab (Seoul) 2015;30(2):142-146. DOI: 10.3803/EnM.2015.30. 2.142

48. Sindhu S, Thomas R, Shihab P, Sriraman D, Behbehani K, Ahmad R. Obesity is a positive modulator of IL-6R and IL-6 expression in the subcutaneous adipose tissue: Significance for metabolic inflammation. PLoS One 2015;10(7):e0133494. DOI: 10.1371/journal.pone.0133494 49. Incio J, Ligibel JA, McManus DT, Suboj P, Jung K, Kawaguchi K, et al. Obesity promotes resistance to anti-VEGF therapy in breast cancer by up-regulating IL-6 and potentially FGF-2. Sci Transl Med 2018;10(432): eaag0945. DOI: 10.1126/scitranslmed.aag0945

50. Saraheimo M, Teppo AM, Forsblom C, Fagerudd J, Groop PH. Dia- betic nephropathy is associated with low-grade inflammation in Type 1 diabetic patients. Diabetologia 2003;46(10):1402-1407. DOI: 10. 1007/s00125-003-1194-5

51. Oda E. High-sensitivity C-reactive protein, but not white blood cell count, independently predicted incident diabetes in a Japanese health screening population. Acta Diabetol 2015;52(2):983-990. DOI: 10. 1007/s00592-015-0788-y

52. Twig G, Afek A, Shamiss A, Derazne E, Tzur D, Gordon B, et al. White blood cells count and incidence of type 2 diabetes in young men. Diabetes Care 2013;36(2):276-282. DOI: 10.2337/dc11-2298

\section{국문초록}

\section{한국인 당뇨병 환자에서 염증 표지자와 혈당 조절과의 관련성}

강 민 ${ }^{1} \cdot$ 손석준 ${ }^{2}$

1전남대학교 대학원 보건학협동과정생, ${ }^{2}$ 전남대학교 의과대학 예방의학교실 교수

목적: 이 연구는 한국 당뇨환자에서 저등급염증과 혈당조절 간의 관계를 평가하는 것을 목적으로 하였다.

방법: 2007-2018년까지의 국민건강영양조사를 바탕으로 19-80세까지의 4,186명의 당뇨환자를 대상으로 진행하였다. 잘못된 혈당조절 은 $\mathrm{HbAlC}$ 가 7미만일 때로 정의하였다. 저등급염증은 염증마커인 WBC counts와 hsCRP로 측정되었으며 모든 염증마커는 사분위수로 구분되었다. 사분위수의 염증마커와 혈당조절 불량은 연령, 교육수준, 소득, 결혼상태, 흡연, 음주, 운동, $\mathrm{BMI}, \mathrm{CAD}$, 고혈압, 빈혈, 고콜레 스테롤혈증을 포함한 혼란변수가 적용된 다변량로지스틱회귀분석을 통해 분석되었다.

결과: 잠재적 혼란변수를 적용한 후에도 WBC counts와 hsCRP는 혈당조절불량과 직선관계를 나타내었다. WBC counts의 경우 첫 번째 4 분위수를 기준으로 하였을 때 혈당조절불량에 대해 두번째 사분위수는 1.50 (95\% confidence intervals, 1.26-1.78), 세번째 사분위수는 1.71 (95\% CI, 1.43-2.05), 네번째 사분위수는 2.0 의 OR 값을 가졌다( $95 \%$ CI 1.67-2.40). HsCRP의 경우 첫 번째 4분위수를 기준으로 하였을 때 혈당조절불량에 대해 두 번째 사분위수는 1.15 (95\% CI, 0.87-1.53), 세 번째 사분위수는 1.59 (95\% CI, 1.20-2.11), 네 번째 사분위수는 1.69 의 OR 값을 가졌다 $(95 \% \mathrm{CI}, 1.27-2.26)$. 층화분석결과 hsCRP와 혈당조절 간의 관련성에 연령과 성별에 따른 차이점이 있었다. 65세 미만인 그룹과 남성 그룹은 $\mathrm{HsCRP}$ 와 혈당조절에서 통계적으로 유의한 직선관계를 나타내었지만 65세 이상인 그룹과 여성그룹은 직선 관계를 보였으나 통계적으로 유의하지 않았다.

결론: WBC counts와 hsCRP는 혈당조절불량의 위험과 통계적으로 유의한 직선관계를 나타내었으나 hsCRP의 경우 연령과 성별에 따 른 차이점이 있었다. 이러한 결과는 한국을 대표하는 한국인 당뇨병환자 표본에서 낮은 등급의 염증이 혈당조절불량과 유의하게 관련 이 있음을 시사한다.

주제어: 백혈구, $\mathrm{C}$ 반응단백, 염증, 당화 헤모글로빈, 당뇨병 